\title{
INFLUENCE OF HUMAN T-CELL LYMPHOTROPIC VIRUS TYPE 1 (HTLV-1) INFECTION ON LABORATORY PARAMETERS OF PATIENTS WITH CHRONIC HEPATITIS C VIRUS
}

Daniela Fernandes CARDOSO(1), Fernando Vieira DE SOUZA(2), Luiz Augusto M. FONSECA(3), Alberto José da Silva DUARTE(4) \& Jorge CASSEB(1,4)

\begin{abstract}
SUMMARY
Hepatitis C virus (HCV) and human T-cell lymphotropic virus type 1 (HTLV-1) share routes of transmission and some individuals have dual infection. Although some studies point to a worse prognosis of hepatitis C virus in patients co-infected with HTLV-1, the interaction between these two infections is poorly understood. This study evaluated the influence of HTLV-1 infection on laboratory parameters in chronic $\mathrm{HCV}$ patients. Twelve HTLV-1/HCV-coinfected patients were compared to 23 patients infected only with HCV, in regard to demographic data, risk factors for viral acquisition, $\mathrm{HCV}$ genotype, presence of cirrhosis, $\mathrm{T} \mathrm{CD} 4^{+}$and $\mathrm{CD} 8^{+}$cell counts and liver function tests. There was no difference in regard to age, gender, alcohol consumption, smoking habits, HCV genotype or presence of cirrhosis between the groups. Intravenous drug use was the most common risk factor among individuals co-infected with HTLV-1. These patients showed higher TCD $8^{+}$counts $(p=0.0159)$ and significantly lower median values of AST and ALT $(p=0.0437$ and 0.0159 , respectively). In conclusion, we have shown that HCV/HTLV-1 co-infected patients differs in laboratorial parameters involving both liver and immunological patterns. The meaning of these interactions in the natural history of these infections is a matter that deserves further studies.
\end{abstract}

KEYWORDS: HCV; HTLV-1; Hepatitis C; Coinfection; Liver enzymes.

\section{INTRODUCTION}

Hepatitis $\mathrm{C}$ virus (HCV) is the major causative agent of chronic liver disease worldwide, with approximately 170 million people infected ${ }^{17,22,25}$. In Brazil, WHO estimates suggest the infection of about three million people ${ }^{17}$. HCV is a single stranded ribonucleic acid (RNA) virus that belongs to the Flaviviridae family ${ }^{29}$ and is transmitted mainly by infected blood. Epidemiological studies have revealed that more than $80 \%$ of acutely HCV-infected patients fail to eradicate the virus, and they subsequently develop chronic hepatitis ${ }^{12,14}$.

Cellular immune responses play an important role in disease pathogenesis. The specific $\mathrm{T} \mathrm{CD} 8^{+}$response to $\mathrm{HCV}$ contributes to the viral clearance, but its action is also responsible for the lysis of hepatocytes and the consequent development of liver damage in the chronic phase ${ }^{3}$. Several factors can influence the outcome of chronic hepatitis $\mathrm{C}$, including age, sex, alcohol consumption ${ }^{15,23}$ and co-infection with other viruses like HIV and HTLV-1 ${ }^{11,23}$.

HTLV-1 is a virus belonging to the Retroviridae family that preferentially infects $\mathrm{CD}^{+} \mathrm{T}$ cells. Like other retroviruses, HTLV-1 causes a lifelong infection and is associated with the development of adult T-cell leukemia (ATL) ${ }^{36}$ and HTLV-1-associated myelopathy ${ }^{21}$.
Some evidences suggest that HTLV-1 causes a functional impairment of the cellular immune response among carriers ${ }^{19,31,35}$.

As we know that the development of liver injury is due to stimulation of the cytotoxic T lymphocyte response ${ }^{3}$, we can suppose that the coinfection between HCV and HTLV-1 may influence the outcome of hepatic disease. Although some studies point to a worse prognosis of hepatitis C in patients co-infected with HTLV-1, the interaction between these two infections is still poorly understood. The aim of this study was determine immunological integrity of patients through $\mathrm{CD}^{+}$and $\mathrm{CD} 8^{+}$ lymphocytes counts, and evaluate the influence of HTLV-1 on some laboratory parameters of patients with chronic HCV infection.

\section{MATERIALS AND METHODS}

From July to November 2007, 23 consecutive untreated patients with chronic hepatitis C from Hepatology Outpatient Clinic followed at "Emilio Ribas" Institute of Infectious Diseases (IIER) were included in this study. Chronic hepatitis $\mathrm{C}$ was defined by detectable anti-hepatitis $\mathrm{C}$ virus (HCV) and serum viral RNA. HTLV-1/HCV co-infected patients were selected from a database made up of patients from the Outpatient HTLV Clinic, also followed at IIER. In total, 621 patients were registered until September 2007 and 373 were infected with HTLV-1. We found 27

Work published as part of the celebration of the $50^{\text {th }}$ anniversary of the São Paulo Institute of Tropical Medicine (1959/2009).

(1) Laboratório Dermatologia e Imunodeficiências LIM-56, Faculdade de Medicina da USP, São Paulo, SP, Brasil.

(2) Clínica de Hepatologia, Instituto de Infectologia "Emilio Ribas", São Paulo, SP, Brasil.

(3) Departamento de Medicina Preventiva da Faculdade de Medicina da USP, São Paulo, SP, Brasil.

(4) Instituto de Medicina Tropical de São Paulo, USP, São Paulo, SP, Brasil.

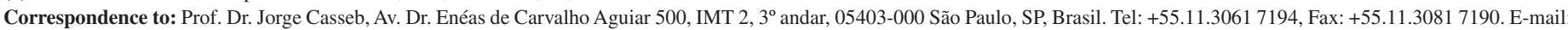
jcasseb@usp.br 
CARDOSO, D.F.; DE SOUZA, F.V.; FONSECA, L.A.M.; DUARTE, A.J.S. \& CASSEB, J. - Influence of human T-cell lymphotropic virus type 1 (HTLV-1) infection on laboratory parameters of patients with chronic hepatitis C virus. Rev. Inst. Med. trop. S. Paulo, 51(6): 325-329, 2009.

patients co-infected with HCV and HTLV-1, from whom only 12 met inclusion criteria.

The exclusion criteria included patients with other causes for liver disease, infection with the hepatitis B virus (HBV), or HIV. None of the patients had received or was receiving antiviral therapy until the time of research. Patients were recruited for a blood sample collection during their periodic clinical evaluation. This study was approved by the Research Ethics Committee of the "Emilio Ribas" Institute of Infectious Diseases and all patients gave their informed consent after being briefed on the research.

All clinical charts were reviewed to obtain information about sociodemographic data, risk factors for HCV and HTLV-1 acquisition, HCV genotype, existence of cirrhosis and results of the following laboratory tests: alanine aminotransferase (ALT), aspartate aminotransferase (AST), gamma glutamyl transferase (GGT), alkaline phosphatase (AP), bilirubin, albumin, globulin and platelet counts. The analyses of all laboratory tests were carried out at the IIER Laboratory.

The diagnosis of cirrhosis was determined by means of a liver biopsy indicating fibrosis grade 4, abdominal ultrasound or clinical evidences. The histological study was carried out at IIER, and included the analysis of the degree of necro-inflammatory activity and the stage of fibrosis, which were assessed using a semi-quantitative scoring system according to METAVIR classification ${ }^{13}$.

To determine the counts of $\mathrm{CD}^{+}$and $\mathrm{CD} 8^{+} \mathrm{T}$-cell subsets, fresh whole blood specimens were collected in EDTA tubes and subjected to flow cytometry $\left(\right.$ Coulter $^{\circledR}$ EPICS $^{\circledR}$ XL-MCL Flow Cytometer - Beckman Coulter, Fullerton, CA), using human monoclonal antibodies anti-CD3, anti-CD4, and anti-CD8, labeled with fluorochrome.

Statistical analysis was performed using Student's t-test for parametric data, and the chi-square test or Fischer's test for nonparametric data. Possible differences in patient characteristics or laboratory values among the groups were evaluated with two-way Mann-Whitney's test and Kruskal-Wallis test. Any $p$ value $<0.05$ was considered significant.

\section{RESULTS}

A total of 35 patients were investigated and their demographic and epidemiological data are shown on Table 1.

There was no statistically significant difference with respect to age, gender, alcohol consumption and smoking among HCV/HTLV-1 patients compared to those with $\mathrm{HCV}$ only. However, with regard to the likely risk of viral acquisition, we observed a statistically significant difference in the proportion of patients who reported the use of intravenous drugs, being higher among co-infected patients $(p=0.01)$. For both groups, a limited number of results from HCV genotypes and liver biopsy or ultrasound were available for analysis. There was no statistically significant difference in regard to HCV genotype among groups. Although the difference was not significant, a relatively lower proportion of coinfected patients had the diagnosis of cirrhosis.

The results of laboratory tests among $\mathrm{HTLV}-1 / \mathrm{HCV}$ and $\mathrm{HCV}$ subjects are shown on Table 2 .
Table 1

Analysis of demographic data and risk factors according to HCV infection status

\begin{tabular}{|c|c|c|c|}
\hline & $\begin{array}{l}\text { HTLV-1 } \\
\text { positive }\end{array}$ & $\begin{array}{l}\text { HTLV-1 } \\
\text { negative }\end{array}$ & \\
\hline Variable & $\mathrm{HCV}+(\mathrm{n}=12)$ & $\mathrm{HCV}+(\mathrm{n}=23)$ & $p$ value $^{\text {a }}$ \\
\hline Age (mean / SD) & $44.9 / 14.7$ & $50.4 / 14.1$ & $N S$ \\
\hline \multicolumn{4}{|l|}{ Gender } \\
\hline Male & $8(66.7 \%)$ & $10(43.5 \%)$ & $N S$ \\
\hline Female & $4(33.3 \%)$ & $13(56.5 \%)$ & $N S$ \\
\hline \multicolumn{4}{|l|}{$\begin{array}{l}\text { Transmission } \\
\text { route }\end{array}$} \\
\hline IDU & $7(58.4 \%)$ & $4(17.4 \%)$ & 0.01 \\
\hline Transfusion & $3(25 \%)$ & $10(43.5 \%)$ & $N S$ \\
\hline $\begin{array}{l}\text { Other / } \\
\text { Ignored }\end{array}$ & $2(16.6 \%)$ & $9(39.1 \%)$ & $N S$ \\
\hline \multicolumn{4}{|l|}{$\begin{array}{l}\text { Alcohol con- } \\
\text { sumption }\end{array}$} \\
\hline Yes & $9(75 \%)$ & $16(69.6 \%)$ & $N S$ \\
\hline No & $3(25 \%)$ & $7(30.4 \%)$ & $N S$ \\
\hline \multicolumn{4}{|l|}{ Smoking } \\
\hline Yes & $8(66.7 \%)$ & $12(52.2 \%)$ & $N S$ \\
\hline No & $4(33.3 \%)$ & $11(47.8 \%)$ & $N S$ \\
\hline \multicolumn{4}{|l|}{ Genotype $^{\text {b }}$} \\
\hline Type 1 & $5(41.6 \%)$ & $14(60.8 \%)$ & $N S$ \\
\hline Other & $1(8.4 \%)$ & $0(0 \%)$ & $N S$ \\
\hline Not done & $6(50 \%)$ & $9(39.2 \%)$ & $N S$ \\
\hline \multicolumn{4}{|l|}{$\begin{array}{l}\text { Presence of } \\
\text { cirrhosis }^{c}\end{array}$} \\
\hline Yes & $1(8.4 \%)$ & $5(21.7 \%)$ & $N S$ \\
\hline No & $6(50 \%)$ & $13(56.5 \%)$ & $N S$ \\
\hline Not done & $5(41.6 \%)$ & $5(21.8 \%)$ & $N S$ \\
\hline
\end{tabular}

SD: Standard deviation; Underlined $p$ values are statistically significant; NS: Not significant; a Student's $t$ test for mean age and Chi-schare test for the others; ${ }^{\mathrm{b}}$ Results available for only 20 patients; ${ }^{\mathrm{c}}$ Results available for only 25 patients.

We observed higher absolute $\mathrm{CD} 8^{+} \mathrm{T}$-cell counts among HCV/HTLV1 co-infected patients. However, for both groups, the values were within the normal ranges. Median values of serum liver enzymes AST, ALT and GGT were above the normal range in patients infected only with HCV. A statistically significant difference was observed in AST $(p=0.0437)$ and ALT ( $p=0.0159$ ) values. No change was observed in bilirubin and albumin levels for both groups. On both groups the median globulin values were above the normal ranges, and higher values were observed among patients infected only with HCV when compared to HCV/HTLV1 individuals ( $p=0.014)$. With respect to platelet counts, there was no difference between groups. 
CARDOSO, D.F.; DE SOUZA, F.V.; FONSECA, L.A.M.; DUARTE, A.J.S. \& CASSEB, J. - Influence of human T-cell lymphotropic virus type 1 (HTLV-1) infection on laboratory parameters of patients with chronic hepatitis C virus. Rev. Inst. Med. trop. S. Paulo, 51(6): 325-329, 2009.

Table 2

Analysis of laboratory results according to HCV infection status

\begin{tabular}{|c|c|c|c|}
\hline \multirow[t]{2}{*}{ Variable $($ mean \pm SD) } & HTLV-1 positive & HTLV-1 negative & \multirow[t]{2}{*}{$p$ value $^{\mathrm{d}}$} \\
\hline & $\mathrm{HCV}+(\mathrm{n}=12)$ & $\mathrm{HCV}+(\mathrm{n}=23)$ & \\
\hline CD4 T cells count & $1670 \pm 364$ & $1159 \pm 456$ & $N S$ \\
\hline CD8 T cells count & $844 \pm 217$ & $598 \pm 276$ & $\underline{0.0159}$ \\
\hline AST level & $36.08 \pm 7.84$ & $61.55 \pm 39.35$ & $\underline{0.0437}$ \\
\hline ALT level & $47.08 \pm 31.84$ & $84.3 \pm 47.12$ & $\underline{0.0159}$ \\
\hline GGT level & $47.27 \pm 39.92$ & $126.7 \pm 129.3$ & $N S$ \\
\hline AP level & $91.3 \pm 37.9$ & $85.93 \pm 37.6$ & $N S$ \\
\hline Total bilirubin level & $1.06 \pm 1.4$ & $0.79 \pm 0.41$ & $N S$ \\
\hline Indirect bilirubin level & $0.80 \pm 1.25$ & $0.59 \pm 0.39$ & $N S$ \\
\hline Direct bilirubin level & $0.25 \pm 0.21$ & $0.19 \pm 0.16$ & $N S$ \\
\hline Total protein level & $7.4 \pm 0.45$ & $7.75 \pm 0.55$ & $N S$ \\
\hline Albumin level & $4.13 \pm 0.52$ & $4.09 \pm 0.39$ & $N S$ \\
\hline Globulin level & $3.12 \pm 0.53$ & $3.64 \pm 0.50$ & $\underline{0.014}$ \\
\hline Platelet count & $218200 \pm 45350$ & $217400 \pm 98930$ & $N S$ \\
\hline
\end{tabular}

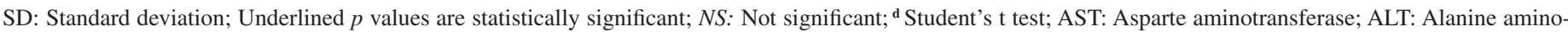
transferase; GGT: Gama glutamyl transferase.

\section{DISCUSSION}

Co-infection HCV/HTLV-1 is a matter of great interest due to the possibility of interactions between these two pathogenic infections. To compare the groups, we first evaluated the profile of the patients. No difference was observed in age, sex, frequent consumption of alcohol and smoking habits between groups. The last two factors are considered to possibly affect the progression of liver injury and consequently cause greater liver damage ${ }^{18,24}$, although they did not influence the results shown here. The higher number of patients who were intravenous drug users suggests that such exposure is an important risk factor for the acquisition of HTLV-1 in our cohort of patients. Thus, we can assume that, just as happens with patients infected with HTLV-2, infection with HTLV-1 may also be linked to drug use and co-infection with $\mathrm{HCV}^{4}$.

The main aim of this study was to relate the presence of infection with HTLV-1 with hepatocellular injury, represented by laboratorial data of liver function, including the dosage of liver enzymes ALT, AST and GGT; quantification of total plasma proteins and their fractions; dosage of bilirubin and platelet count. We were able to demonstrate differences in concentrations of liver enzymes. In fact, ALT and AST levels were statistically lower among HCV/HTLV-1 patients than those infected with $\mathrm{HCV}$ alone.

AST is a mitochondrial enzyme present in large quantities in the heart, liver, kidney and skeletal muscle. Its serum levels increase when these tissues suffer destruction, probably due to release from injured cells. ALT is a cytosolic enzyme also present in the liver and increased serum levels are more specific for liver injury than AST, because a greater proportion is found in the liver compared to the heart and skeletal muscles ${ }^{26}$. Although histological findings on liver biopsy are fundamental to the detection of liver disease as well as their intensity, hepatic enzymes changes are also used as a biochemical marker for HCV infection and its utility on predicting liver damage is described on several studies s, $5-7,16,27,37^{\text {. For }}$ example, there is evidence that patients with $\mathrm{HCV}$ and normal values of ALT have milder hepatic injury than those with elevated ALT values ${ }^{5,7,16,27}$. Some authors also correlated serum ALT and AST levels with histologic activity score, parameters of disease severity ${ }^{27,37}$ and extent of fibrosis ${ }^{1}$.

Although there was no statistically significant difference, higher values of GGT were observed among the group infected solely by HCV, in spite of the absence of significant differences in alcohol consumption. Some authors associated high levels of GGT with more intense necroinflammatory activity, suggesting that GGT activity is associated with necrosis of hepatocytes. Levels of GGT are also related to the degree of hepatic fibrosis ${ }^{28}$.

Liver diseases may affect the concentration of circulating plasma proteins. The results did not demonstrate any decrease in total plasma protein concentration, but the estimation of total plasma protein is not accurate. In fact, the serum albumin concentration is more specific and widely accepted as a test of liver function, since it reflects the hepatic protein synthesis. Likewise no difference between groups and albumin concentration was inside normal values, we can assume that in both groups the protein hepatic synthesis was preserved. Although on both groups globulin level was above normal ranges, this increase was lower during HCV/HTLV-1 co-infection. However, globulin is a very heterogeneous fraction of plasma proteins, and it is difficult to draw a correct conclusion without knowing what fraction would be increased in each case. It would be necessary to separate protein fractions through electrophoresis, what would enable us answering that question. 


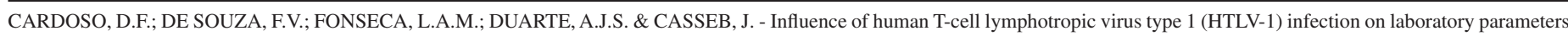
of patients with chronic hepatitis C virus. Rev. Inst. Med. trop. S. Paulo, 51(6): 325-329, 2009.

Taken together, on both groups of patients hepatic function was preserved, but co-infected patients have less hepatic injury. Other authors have already demonstrated similar results. Unpublished data from Miyazaki Cohort Study indicated a possible negative interaction between HTLV-1 and HCV with respect to abnormal levels of ALT, with the prevalence of elevated ALT levels being lower in co-infected subjects than in subjects with HCV alone. Researchers from Japan reported a similar effect of co-infection on ALT levels ${ }^{8}$.

Based on these findings, some authors have postulated that coinfection with HTLV-1 can reduce the immune-mediated acute damage to hepatocytes infected with $\mathrm{HCV}$ thereby decreasing the release of ALT. At the same time, co-infection increases the persistence of $\mathrm{HCV}$ infection and, subsequently, the risk of developing liver disease ${ }^{30}$. As several studies have suggested, liver damage is related mainly to immune mediated mechanisms, with the stimulation of cytotoxic T cell (CTL) response against hepatocytes infected with $\mathrm{HCV}^{9,10,20,32}$. This response would lead to hepatocyte lysis and consequent increased release of liver transaminases in plasma.

We also analyzed the number of $\mathrm{CD}^{+}$and $\mathrm{CD} 8^{+} \mathrm{T}$ cells. Although within the normal ranges, we have seen higher $\mathrm{CD} 8^{+} \mathrm{T}$ lymphocyte cells among co-infected patients, probably due to response to Tax protein of HTLV- $1^{33}$. Despite this increased number of $\mathrm{CD}^{+} \mathrm{T}$ cell, there is a reduction of functional immune response, especially of cellular immunity in HTLV-1-infected carriers ${ }^{19,31}$. In persons co-infected with HTLV-1 and $\mathrm{HCV}$, it is possible to infer that infection of T cells by HTLV-1 may interfere with the CTL response to $\mathrm{HCV}$-infected hepatocytes ${ }^{2}$.

During the acute phase of infection, a potent T-cell response would be an important factor for viral clearance. However, in the chronic phase, the activation of CTLs leads to progressive liver damage. We could then assume that since the anti-HCV response could be impaired in HTLV-1 patients, the lysis of hepatocytes infected with HCV would be minor. However, this hypothesis should be tested elsewhere.

Thus, in HCV/HTLV-1 co-infected patients, there probably is lower immune mediated liver injury, but other factors associated with HTLV-1 can influence the disease progression, as described in previous works ${ }^{2,30}$. Despite the small sample size of this study, the HCV/HTLV-1 subjects showed lower liver enzymatic levels than solely HCV infected subjects. This may delay liver biopsy or/and specific anti-HCV treatment. Finally, more studies should be done with this population to address histological damage, response to treatment and progression to liver disease.

\section{RESUMO}

\section{Influência da infecção pelo vírus linfotrópico humano tipo 1 (HTLV-1) em parâmetros laboratoriais de pacientes com hepatite $\mathbf{C}$ crônica}

$\mathrm{O}$ vírus da hepatite $\mathrm{C}$ (VHC) e vírus linfotrópico humano tipo 1 (HTLV-1) compartilham formas de transmissão e algumas pessoas apresentam coinfecção. Embora alguns estudos apontem para um pior prognóstico da infecção pelo VHC em pacientes coinfectados com HTLV-1, a interação entre estas infecções é mal compreendida. Este estudo avaliou a influência da infecção pelo HTLV-1 em parâmetros laboratoriais de pacientes com VHC. 12 coinfectados VHC/HTLV-1 foram comparados com 23 pacientes monoinfectados com VHC, no que diz respeito aos dados demográficos, fatores de risco para aquisição viral, genótipo do VHC, presença de cirrose, contagens de linfócitos T CD4+ e $\mathrm{CD}^{+}$e testes de função hepática. Não houve diferença em relação à idade, sexo, consumo de álcool, tabagismo, genótipo do VHC ou presença de cirrose entre os grupos. O uso de drogas injetáveis foi o fator de risco mais comum entre coinfectados. Esses pacientes apresentaram maiores contagens de linfócitos T CD8 ${ }^{+}$e valores medianos de AST e ALT significativamente mais baixos ( $p=0,0437$ e 0,0159 , respectivamente). Em conclusão, demonstrou-se que os pacientes com VHC/HTLV-1 diferem quanto aos parâmetros hepáticos e imunológicos. O significado destas diferenças na história natural destas infecções é um assunto que merece estudos mais aprofundados.

\section{ACKNOWLEDGMENTS}

The authors thank Mario Gonzalez and Rosemary Lorenzo for their assistance in this work and Dana Gallo for revising this manuscript. The authors are grateful to patients who contributed to this study.

\section{ETHICAL APPROVAL}

This study was approved by the Research Ethics Committee of the "Emilio Ribas" Institute of Infectious Diseases, and all patients signed their informed consent.

\section{REFERENCES}

1. ASSY, N. \& MINUK, G.Y. - Serum aspartate but not alanine aminotransferase levels help to predict the histological features of chronic hepatitis $\mathrm{C}$ viral infection in adults. Amer. J. Gastroent., 95: 1545-1550, 2000

2. BOSCHI-PINTO, C.; STUVER, S.; OKAYAMA, A. et al. - A follow-up study of morbidity and mortality associated with hepatitis $\mathrm{C}$ virus infection and its interaction with human T lymphotropic virus type I in Miyazaki, Japan. J. infect. Dis., 181: $35-41,2000$.

3. CHISARI, F.V. - Cytotoxic T cells and viral hepatitis. J. clin. Invest., 99: 1472-1477, 1997.

4. DE LA FLUENTE, L.; TORO, C.; SORIANO, V. et al. - HTLV infection among young injection and non-injection heroin users in Spain: prevalence and correlates. J. clin. Virol., 35: 244-249, 2006.

5. DE SANTANA, N.P.; DE FREITAS, L.A.; LYRA, A.C. et al. - Liver histological alterations in patients with chronic hepatitis $\mathrm{C}$ and normal ALT levels in the city of Salvador, Northeast-Brazil. Braz. J. infect. Dis., 9:134-141, 2005.

6. GORDON, S.C.; FANG, J.W.S.; SILVERMAN, A.L.; McHUTCHINSON, J.G. \& ALBRECHT, J.K. - The significance of baseline serum alanine aminotransferase on pretreatment disease characteristics and response to antiviral therapy in chronic hepatitis C. Hepatology, 32: 400-404, 2000.

7. JAMAL, M.M.; SONI, A.; QUINN, P.G. et al. - Clinical features of hepatitis C-infected patients with persistently normal alanine transaminase levels in the southwestern United States. Hepatology, 30:1307-1311, 1999.

8. KAMIHIRA, S.; MOMITA, S.; IKEDA, S. et al. - Cohort study of hepatotropic virus and human $\mathrm{T}$ lymphotropic virus type-I infections in an area endemic for adult $\mathrm{T}$ cell leukemia. Jap. J. Med., 30: 492-497, 1991

9. KAWAMURA, T.; FURUSAKA, A.; KOZIEL, M.J. et al. - Transgenic expression of hepatitis C virus structural proteins in the mouse. Hepatology, 25: 1014-1021, 1997. 
CARDOSO, D.F.; DE SOUZA, F.V.; FONSECA, L.A.M.; DUARTE, A.J.S. \& CASSEB, J. - Influence of human T-cell lymphotropic virus type 1 (HTLV-1) infection on laboratory parameters of patients with chronic hepatitis C virus. Rev. Inst. Med. trop. S. Paulo, 51(6): 325-329, 2009.

10. KERR, J.F.R.; COOKSLEY, W.G.; SEARLE, J. et al. - The nature of piecemeal necrosis in chronic active hepatitis. Lancet, 2(8147): 827-828, 1979.

11. KISHIHARA, Y.; FURUSYO, N.; KASHIWAGI, K. et al. - Human T lymphotropic virus type 1 infection influences hepatitis $C$ virus clearance. J. infect. Dis., 184: 1114-1119, 2001.

12. LAUER, G.M. \& WALKER, B.D. - Hepatitis C virus infection. New Engl. J. Med., 345: 41-52, 2001.

13. LEFKOWITCH, J.H. - Liver biopsy assessment in chronic hepatitis. Arch. med. Res., 38: 634-643, 2007.

14. LIANG, T.J.; REHERMANN, B.; SEEF, L.B. \& HOOFNAGLE, J.H. - Pathogenesis, natural history, treatment, and prevention of hepatitis C. Ann. intern. Med., 132: 296-305, 2000.

15. MARCELLIN, P.; ASSELAH, T. \& BOYER, N. - Fibrosis and disease progression in hepatitis C. Hepatology, 36 (5 suppl. 1): S47-S56, 2002.

16. MATHURIN, P.; MOUSSALLI, J.; CADRANEL, J.F. et al. - Slow progression rate of fibrosis in hepatitis $\mathrm{C}$ virus patients with persistently normal alanina transaminases activity. Hepatology, 27: 868-872, 1998.

17. MEMON, M.I. \& MEMON, M.A. - Hepatitis C: an epidemiologic review. J. viral Hepat., 9: 84-100, 2002.

18. MODI, A.A. \& LIANG, T.J. - Hepatitis C: a clinical review. Oral Dis., 14: 10-14, 2008

19. MURAI, K.; TACHIBANA, N.; SHIOIRI, S. et al. - Suppression of delayed-type hypersentivity to PPD and PHA in elderly HTLV-I carriers. J. acquir. immune Defic. Syndr., 3: 1006-1009, 1990.

20. NAOUMOV, N.V. - Hepatitis C virus-specific CD4+ T cells: do they help or damage? Gastroenterology, 117: 1012-1014, 1999.

21. OSAME, M.; USUKU, K.; IZUMO, K. et al. - HTLV-I associated myelopathy, a new clinical entity. Lancet, 1(8488): 1031-1032, 1986.

22. PAWLOTSKY, J.M. - Therapy of hepatitis C: from empiricism to eradication. Hepatology, 43(2 suppl. 1): S207-S220, 2006.

23. POYNARD, T.; BEDOSSA, P. \& OPOLON, P. - Natural history of liver fibrosis progression in patients with chronic hepatitis C. The OBSVIRC, METAVIR, CLINIVIR, and DOSVIRC groups. Lancet, 349(9055): 825-832, 1997.

24. PRESSIONE, F.; RAMOND, M.J.; NJAPOUM, C. et al. - Cigarette smoking and hepatic lesions in patients with chronic hepatitis C. Hepatology, 34: 121-125, 2001.

25. SHEPARD, C.W.; FINELLI, L. \& ALTER, M.J. - Global epidemiology of hepatitis $\mathrm{C}$ virus infection. Lancet infect. Dis., 5: 558-567, 2005.
26. SHERLOCK, S. \& DOOLEY, J. - Diseases of the liver and biliary system. 11. ed. Rio de Janeiro, Guanabara Koogan, 2004.

27. SHINDO, M.; ARAI, K.; SOKAWA, Y.S. \& OKUNO, T. - The virological and histological states of anti-hepatitis $\mathrm{C}$ virus-positive subjets with normal biochemical values. Hepatology, 22: 418-425, 1995

28. SILVA, I.S.S.; FERRAZ, M.L.C.G.; PEREZ, R.M. et al. - Role of gamma-glutamyl transferase activity in patients with chronic hepatitis $\mathrm{C}$ virus infection. J. Gastroent. Hepat., 19: 314-318, 2004

29. SIMMONDS, P.; BUKH, J.; COMBET, C. et al. - Consensus proposals for a unified system of nomenclature of hepatitis C virus genotypes. Hepatology, 42: 962-973, 2005.

30. STUVER, S.O.; BOSCHI-PINTO, C.; OKAYAMA, A. \& MUELLER, N. - Author reply. J. infect. Dis., 182: 379-380, 2000.

31. TACHIBANA, N.; OKAYAMA, A.; ISHIZAKI, J. et al. - Suppression of tuberculin skin reaction in healthy HTLV-I carriers from Japan. Int. J. Cancer., 42: 829-831, 1988.

32. TAKAKU, S.; NAKAGAWA, Y.; SHIMIZU, M. et al. - Induction of hepatic injury by hepatitis $\mathrm{C}$ virus specific CD8 (+) murine cytotoxic lymphocytes in transgenic mice expressing the viral structural genes. Biochem. Biophys. Res. Commun., 301: 330-337, 2003.

33. URETA-VIDAL, A.; PIQUE, C.; GARCIA, Z. et al. - Human T-cell leukemia virus Type I (HTLV-I) infection induces greater expansions of CD8 T Iymphocytes in persons with HTLV-I-associated myelopathy/tropical spastic paraparesis than in asymptomatic carriers. J. infect. Dis., 183: 857-864, 2001.

34. WAKITA, T.; KATSUME, A.; KATO, J. et al. - Possible role of cytotoxic T cells in acute liver injury in hepatitis $\mathrm{C}$ virus cDNA mice mediated by Cre/loxP system. J. med. Virol., 62: 308-317, 2000.

35. WELlES, S.L.; TACHIBANA, N.; OKAYAMA, A. et al. - Decreased reactivity to PPD among HTLV-I carriers in relation to virus and hematologic status. Int. J. Cancer, 56: 337-340, 1994.

36. YOSHIDA, M.; MIYOSHI, I. \& HINUMA, Y. - Isolation and characterization of retrovirus from cell lines of human adult T-cell leukemia and its implication in the disease. Proc. nat. Acad. Sci. (Wash.), 79: 2031-2035, 1982.

37. ZECHINI, B.; PASQUAZZI, C. \& ACETI, A. - Correlation of serum aminotransferases with HCV RNA levels and histological findings in patients with chronic hepatitis $\mathrm{C}$ : the role of serum aspartate transaminase in the evaluation of disease progression. Europ. J. Gastroent. Hepat., 16: 891-896, 2004.

Received: 7 July 2009

Accepted: 7 October 2009 